\title{
Kamuda Bir İstihdam Modeline Dönüşen Alt İşverenlik*
}

\author{
Muzaffer $\mathrm{KOÇ}^{*}$
}

\begin{abstract}
Öz
İş hukuku, işçi ve işveren arasındaki ilişkileri düzenleyen ve inceleyen bir hukuk dalıdır. İş hukukunda asıl olan işverenin kendi işçisi ile mal veya hizmet üretmesidir. Söz konusu işlerin başka işverenlere verilmesi istisnai durumdur ve ancak Kanunun öngördüğü sınırlar içerisinde gerçekleştirilebilir. Alt işverenlik, işverene işyerindeki mal veya hizmet üretimini başka bir işverenin işçileri vasıtasıyla gerçekleştirme imkânı sağlayan bir uygulamadır.

Günümüzde yoğun bir uygulama alanı bulan alt işverenlik bir nevi "istihdam modeli” hüviyetine dönüşmüştür. Türkiye'de resmi kayıtlara göre yaklaşık 1,5 milyon alt işveren işçisi bulunmaktadır.

Alt işveren işçilerinin ücret, kıdem tazminatı, yıllık izin gibi özlük haklarına yönelik sorunları bulunmaktadır. Son dönemde yapılan bazı yasal düzenlemelerle kamu kurum ve kuruluşlarda çalıştırılan alt işveren işçilerine yönelik ücret, kıdem tazminatı ve yıllık iznin haklarına ilişkin bir takım iyileştirmeler yapılmıştır. Bu çalışmada kamu sektöründe alt işveren işçilerinin sorunlarına yönelik tespitler, alt işverenliği doğuran sebepler, ortaya çıkan sorunlar ve çözüm önerileri güncel gelişmeler ışı̆̆ı̆ında tartışılmıştır.
\end{abstract}

Anahtar kelimeler: Alt İşveren, Asıl İşveren, Birlikte Sorumluluk, Kıdem Tazminatı

\section{The Practice of Subcontracting Which Has Turned into an Employement Model in the Public Sector}

\begin{abstract}
Labour law is a branch of law that regulates and investigates the relationship between employers and employees. It is primary in the labour law that the main employer produces goods and service with its own employees. It is an exceptional case to sublet these works to other employers and this can be made within the limits that are stipulated by the law. Subcontracting is a practice which gives employers the

\footnotetext{
* Bu çalışma, 15-17 Ekim 2015 tarihleri arasında Konya’da düzenlenen 13. Kamu Yönetimi Forumunda sunulan aynı başlıklı bildirinin genişletilmiş ve güncelleştirilmiş halidir.

** Doç. Dr., Marmara Üniversitesi
} 
opportunity to perform the production of goods or services in the workplace by another employer's employees.

Subcontracting, which is finding itself intense application arena in today's world, has been transformed into the nature of an "employment model". According to the official records, there are existing 1.5 million subcontractor employees in today' Turkey.

There are problems existing regarding employment rights of the subcontractor's employees, such as wages, severance payments, annual paid leave. With some legal arrangements in the last years, some improvements are being done in the employment rights of the subcontractor's employees who are working at public institutions and organisations, regarding wages, severance payments, and annual paid leave rights. In this study, determinations regarding problems of the subcontractor's employees' in the public sector, the reasons for subcontracting practices, the problems emerging from this practice, and solutions for this problems are being discussed within the light of current developments.

Keywords: Subcontractor, Main Employer, Joint Responsibility, Severance Payment

\section{Giriş}

Çalışma hayatının dinamik yapısı, teknolojik gelişmelerin sebep olduğu yeni uzmanlık alanlarının ortaya çıkışı ve kıran kırana rekabetin varlığı, mevcut çalışma biçimlerinin değişme sürecine girmesine sebep olmuş; yeni çalışma biçimlerinin hukuki alt yapılarının oluşturulması gereği ortaya çıkmıştır. Bu değişim ve ihtiyacın neticesinde 4857 sayılı İş Kanunu (2003) alt işveren kurumunu yeniden düzenlemiştir. Başka bir işverenden iş alan ve işçilerini söz konusu işverene ait işyerinde çalıştıran işveren olarak tanımlanabilen alt işveren, literatür ve uygulamada, taşeron ve aracı olarak da adlandırılmaktadır. Günümüzde yoğun bir uygulama alanı bulan alt işverenlik bir nevi "istihdam modeli” hüviyetine dönüşmüştür. Söz konusu dönüşümle alt işverenlik kurumuna ve alt işveren işçilerine yönelik çeşitli problemler ortaya çıkmıştır.

İş Hukukunda asıl olan, işverenin kendi işçisi ile mal veya hizmet üretmesidir. Söz konusu işlerin başka işverenlere vermesi istisnai durumdur ve ancak Kanunun öngördügü sınırlar içerisinde gerçekleştirilebilir. Türkiye'de resmi kayıtlara göre yaklaşık 1,5 milyon alt işveren işçisi bulunmaktadır (ÇSGB, 2015). Alt işveren işçilerinin ücret, kıdem tazminatı, yıllık izin gibi özlük haklarına yönelik sorunları bulunmaktadır. Son dönemde yapılan bazı yasal düzenlemelerle kamu kurum ve kuruluşlarda çalıştırılan alt işveren işçilerine yönelik ücret, kıdem tazminatı ve yıllık iznin haklarına ilişkin bir takım iyileştirmeler yapılmıştır.

Kamuda alt işverenlik, siyasi partilerin son dönem seçim beyannamelerinin önemli bir gündem maddesini oluşturmuş ve alt işveren çalışanlarına yönelik çeşitli çözüm önerileri getirilmiştir. 64. Hükümetin 2016 Yılı Eylem Planında asıl-alt işverenlik çerçevesinde asıl işlerde çalışanların

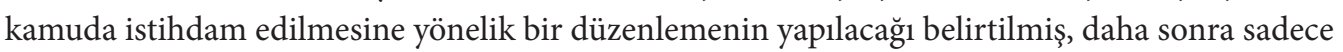


asıl işlerde çalışan alt işveren iş̧̧ilerinin değil; yardımcı işlerde çalışan alt işveren işçilerinin de kamuda kadroya geçirileceğine ilişkin açıklamalar yapılmıştır. Konuya ilişkin çalışmaların devam ettiği kamuoyuna yansımıştır.

$\mathrm{Bu}$ çalı̧̧mada alt işveren kavramı ve unsurları ortaya konulmuş, Türkiyede alt işverenliğin tarihi gelişimi ve mevcut durumu değerlendirilmiş, alt işverenlik sorunları ve çözüm önerileri güncel gelişmeler ışığında tartışılmıştır.

\section{ASIL IŞVEREN - ALT işVEREN ILIŞKISi}

\section{A. Genel Olarak}

Bir işverenin işyerinde yürüttüğü faaliyetleri kendi personeliyle yerine getirmesi olağan bir durum iken çeşitli mali ve teknik sebeplerden dolayı işverenlerin, bazen işin bir bölümünü başka bir işverenin işçileri vasıtasıyla yapmaları da söz konusu olabilmektedir (Akyiğit, 2015:28). Özellikle, teknolojik gelişmelerin ortaya çıkardığı yeni uzmanlık alanları, maddi imkânsızlıklar, kamudaki kadro kısıtlığı, amansız rekabet şartları gibi bir takım ekonomik ve teknik sebeplerden dolayı işverenler, kendi istihdam ettikleri işçilerle birlikte başka işverenin işçilerinin devreye girdiği alt işveren ilişkisi gibi düzenlemelere de yönelmektedirler (Şahlanan, 2014:469-476). 1980'li yıllardan itibaren küreselleşme süreci, ekonomik ve teknolojik gelişmeler işletmeleri, üretim ve istihdamı dışsallaştırma stratejilerine; yani, işyerlerinde gerçekleştirecekleri hizmet ve mal üretimini, kendi işçileriyle birlikte başka işveren ve onun işçileri aracılığıyla gerçekleştirme yoluna sevk etmiştir (Güzel, 2010:15). Günümüzde istihdamın dişsallaşması artan bir ivme ile yaygınlaşmaktadır. İstihdamın dışsallaştırılmasının en eski ve yaygın görünen biçimi, alt işverenliktir (Yenisey, 2009:19). Alt işverenlik, işverene işyerindeki mal veya hizmet üretimini başka bir işverenin işçileri vasıtasıyla gerçekleştirme imkânı sağlayan bir uygulamadır (Kalkınma Bak. 2014:68).

Alt işverenlik İş Hukuku tarafından yasaklanmamakla birlikte temel bir istihdam modeli olarak değil; bir istisna model olarak değerlendirilmektedir. Bu nedenle alt işverenlik kapsamında işçilerin korunması amacıyla önemli güvenceler ve sınırlamalar getirilmektedir (Güzel, 2010:15).

\section{B. Alt İşveren Kavramı}

Alt işveren, başka bir işverenden iş alan ve işçilerini söz konusu işverene ait işyerinde çalıştıran işverendir. Bu bağlamda alt işverenlikte bir işverenin işinin bir kısmını, bir parçasını, aralarındaki sözleşmeye göre bir başka işverene terk etmesi olgusu gerçekleşmelidir (Mollamahmutoğlu, 2004).

1475 sayılı İş Kanunu’nda "diğer işveren" kavramı olarak ifade edilen alt işverenlik, özellikle artış göstermeye başladığı 1980'li yıllardan sonra, "taşeron", "tali işveren", "alt ısmarlanan", "alt işveren", "alt işletici", "aracı", "ikinci işveren" gibi kavramlarla da ifade edilmiştir (Şafak, 2004:113; 
Aykaç, 2010:12). 2013 tarihli 4857 sayılı İş Kanunu’nda söz konusu ilişki "alt işveren" kavramıyla düzenlenmiştir.

4857 sayllı İş Kanunu’nun 2 maddesine göre "bir işverenden, işyerinde yürüttü̈̆̈̈ mal veya hizmet üretimine ilişkin yardımcı işlerinde veya asıl işin bir bölümünde işletmenin ve işin gereği ile teknolojik nedenlerle uzmanlık gerektiren işlerde iş alan ve bu iş için görevlendirdiği iş̧̧ilerini sadece bu işyerinde aldiğı işte çalş̧tran diğger işveren ile iş aldığı işveren arasında kurulan ilişkiye asıl işveren-alt işveren iliş̧kisi denir." Alt işveren Yönetmeliğinin 3 maddesinde ise alt işveren, "bir işverenden, işyerinde yürütülen mal veya hizmet üretimine ilişkin yardımcı işlerde veya asıl işin bir bölümünde işletmenin ve işin gereği ile teknolojik nedenlerle uzmanlik gerektiren işlerde iş alan, bu iş için görevlendirdiği iş̧̧ilerini sadece bu işyerinde aldiğ i işte çalıştıran gerçek veya tüzel kişiyi yahut tüzel kişiliği olmayan kurum ve kuruluşları" şeklinde tanımlanmıştır.

5510 sayılı Kanunu’nun 12 maddesinde de alt işveren, bir işverenden, işyerinde yürüttüğü mal veya hizmet üretimine ilişkin bir işte veya bir işin bölüm veya eklentilerinde, iş alan ve bu iş için görevlendirdiği sigortalıları çalıştıran üçüncü kişi şeklinde tanımlanmıştır.

Alt işveren, başka bir işverenle iş sözleşmesi niteliğinden farklı bir sözleşme yapmaktadır. Alt işveren kavramı ile karıştııılan kavramların başında yüklenici (müteahhit) kavramı gelmektedir. Türk Dil Kurumu tarafından yüklenici, "başkası için yapı ve ticaretle ilgili bir işi yapmayı üstüne alan kimse, üstenci” (TDK,2015) şeklinde tanımlanmaktadır.

Müteahhit kavramı esas itibariyle Borçlar Kanununun istisna akdini (eser sözleşmesi) düzenleyen hükümlerinde düzenlenmiştir. 6098 Sayılı Türk Borçlar Kanunu "müteahhit" yerine "yüklenici" kavramını tercih etmiştir (TİSK, 2012:17). 6098 sayılı Borçlar Kanunu’nun 470. maddesinde eser sözleşmesi, yüklenicinin bir eser meydana getirmeyi, iş sahibinin de bunun karşllğ̆ında bir bedel ödemeyi üstlendiği sözleşmedir. Yüklenici, meydana getirilecek eseri doğrudan doğruya kendisi yapmak veya kendi yönetimi altında yaptırmakla yükümlüdür.

Uygulamada alt işvereni ifade etmek üzere kullanılan kavramlardan biri olan "aracı" kavramı, 3008 sayılı Kanunun 1950 yılında 5518 sayılı Kanunla değiştirilen ilgili hükümde de kullanılmıştır (Aykaç, 2010:18).

\section{Alt İşverenin Unsurları}

Asıl-alt işveren ilişkisi belli şartların varlığı halinde söz konusu olabilmektedir. Söz konusu şartlar 4857 Sayılı İş Kanunu çerçevesinde aşağıdaki şekilde sıralanabilir (Koç,2005:87-98).

1. Assl işverenin kendine ait işyerinde faaliyet göstermesi

2. Alt işverenin asıl işverene ait işyerinde işçi istihdam etmesi

3. İşyerinde yürütülen mal/hizmet üretimine ilişkin yardımcı işler

4. Assl işin bir bölümünde işletmenin ve işin gereği ile teknolojik nedenlerle uzmanlık gerektiren işler 
5. Alt işverenin işçilerinin daha önce asıl işverenin işçileri olarak çalışmış olmaları halinde haklarının kısıtlanamayacağı

6. Alt işverenin işçilerinin sadece asıl işverene ait işyerinde çalıştırması

\section{Asıl İşverenin Kendine Ait İşyerinde Faaliyet Göstermesi}

Asıl işverenin öncelikle İş Kanunu bakımından "işveren” olma şartlarını taşıması gereklidir. İş Kanununda işveren bir takım şartlara bağlı olarak ortaya çıkmaktadır. İşveren, işçi çalıştıran gerçek veya tüzel kişiye yahut tüzel kişiliği olmayan kurum ve kuruluşlardır (4857/2). İşveren kavramı temelde, işçi kavramından çıkmaktadır. Bu bağlamda işveren, "başka birisini iş̧̧i olarak istihdam eden kimse" olarak tanımlanabilir (Turan,1990:252).

İşveren gerçek kişi olabileceği gibi, şirket, dernek, vakıf, kooperatif, sendika, devlet, devlet ya da iktisadi devlet kuruluşu gibi özel hukuku veya kamu hukuku tüzel kişisi veyahut tüzel kişiliği olmayan kurum ve kuruluşlar da olabilir (Çelik, 1994:47). Bu bağlamda önemli olan, işverenin kamu tüzel kişisi veya tüzel kişiliği olmayan kurum ve kuruluşu olması değil, iş̧̧i ile arasındaki ilişkinin özel hukuka dayanmasıdır. Tüzel kişiliği olmamakla birlikte, örneğin bakanlıklar işçi çalıştırmaları halinde işveren sayılırlar.

Asıl işverenin İş Kanununu kapsamında kendisine ait işyerinde faaliyet göstermesi gereklidir. İşyeri, işveren tarafından mal veya hizmet üretmek amacıyla maddî olan ve olmayan unsurlar ile işçinin birlikte örgütlendiği birimdir (4857/2).

\section{Alt İşverenin Asıl İşverene Ait İşyerinde İşçi İstihdam Etmesi}

Alt işverenin asıl işverene ait işyerinde işçi istihdam etmesi gereklidir. Alt işveren, asıl işverene ait işyerinde kendi iş̧̧ileriyle mal/hizmet üretmektedir. Alt işveren kendi işçileri bakımından işveren niteliğini haizdir (Süzek, 2009:142). Belirtilmelidir ki, hem asıl işveren hem da alt işveren işçi çalıştırdıklarından her ikisi de hukuken işverendir. Asıl işveren kendi işçilerine göre işveren sıfatı aldığı gibi, alt işveren de kendi işçilerine göre bu sıfatı kazanmaktadır (Mollamahmutoğlu, 2004).

Gerçek/tüzel kişi/tüzel kişiliği olmayan kurum ve kuruluşu olabilen alt işverenin, işçileriyle iş sözleşmesi bağlamında ilişki içinde olmalı ve doğal olarak işçi çalıştırmalıdır. Alt işverenin işçi çalıştırmayıp doğrudan kendisinin işi üstlenerek yapması halinde alt işverenlikten bahsedilemez (Süzek, 2009:143)

Alt işverenlik konusunda, uygulamada en fazla sıkıntı yaşanan durumlardan biri de, alt işverenin "işveren" kimliğinden kaynaklanmaktadır. Zira uygulamada, bazı durumlarda asıl işveren alt işveren ilişkisinde alt işverenin "işveren" kimliği oluşmamaktadır. Bazı durumlarda alt işverenler, "fiili ve hukuki işveren" olmaktan ziyade; sadece "kaydi işveren" "bordro işveren" şeklinde ortaya çıkmaktadır. Ücret bordrolarında, SGK bildirgelerinde, muhtasar beyannamelerinde işçiler, alt işverenin adına işlem görmelerine rağmen, fiili olarak çalıştırılan işçilerin, işe alımlarında, 
çalıştırılmalarında, emir ve talimat verilmesinde, iş sözleşmelerinin feshinde alt işverenler müdahil olamamaktadırlar. Başka bir ifadeyle, işyerinde çalıştırılan alt işveren işçileri dolaylı/ doğrudan asıl işverenden talimat almakta; onun direktiflerine göre hareket etmektedirler. Dahası, bazı durumlarda alt işverenin işçileri, alt işvereni dahi bilememekte, kendilerini asıl işverenin işçileri şeklinde kabul etmektedirler. Özellikle kamu işyerlerinde karşılaşılan bu durum, alt işverenlik kurumunun kaydi bir takım formalitelerin ötesine gidilmediği imajını vermektedir.

Şüphesiz, asıl işveren, alt işverene işi veren, işyerini sevk ve idare eden ve sadece kendi işyerinde çalıştırılan alt işverenin işçilerinden müteselsil sorumlu bulunan kişi olarak, genel olarak işyerinde genel kaide ve kurallar koyması, buna uygun emir ve talimatlar vermesi doğaldır. Ancak, vurgulanmak istenen, alt işverenin "işveren" olarak çalıştırılan işçilerine talimat verme yetkisinin bulunduğu, çalıştıracağ iş̧̧inin işe alım ve çıkışında söz sahibi olması gerektiği gerçeğidir. Aksi durumda, bir asıl işverenlik alt işverenlik ilişkisinden ziyade, "personel temini" "bordro işverenliğì" söz konusu olacaktır.

\section{Alt İşverenin Daha Önce Asıl İşverenin İşçisi Olarak Çalışmamış Olması}

İş Kanunuınun 2. maddesinde alt işverenlere özel bir yasak getirilmiştir. Maddeye göre “...daha önce o işyerinde çalıştırılan kimse ile alt işveren ilişkisi kurulamaz". Başka bir ifadeyle, asıl işverenin işçisi olarak çalışan kimse, aynı işveren ile alt işveren ilişkisine giremeyecektir. Çok kesin bir yasaklama getiren bu düzenlemenin, Anayasa’nın “çalışma ve sözleşme hürriyeti” başlıklı 48 . maddesinin "herkes, dilediği alanda çalıșma ve sözleşme hürriyetlerine sahiptir. Özel teşebbüsler kurmak serbesttir." hükmü karşısındaki durumu, öğretide doğal olarak tartışılmaktadır.

Daha önceki uygulamalarda, söz konusu durumun kanuna taşınmasına sebep olan kötü örnekler söz konusu idi. Ancak, bu hükmü genelleştirmenin uygulamada sıkıntılara sebep olacağ 1 gözden kaçırılmamalıdır. Kanunda, kötüye kullanılmanın asıl kabul edilip, ona göre düzenleme yapılması, öğretide haklı olarak eleştirilmektedir (Şahlanan, 2014). Bu konuda da Medeni Kanunda belirtilen hukukun temel ilkelerinden iyiniyet prensibinin işletilmesi gereklidir. Çünkü, ilişkilerde iyiniyet asıl; kötüniyet istisnadır. Ancak, alt işveren konusunda, adeta kötü niyetin asıl kabul edilip, iyiniyetin ise istisnai hale getirilmesi, temel hukuk kuralına aykırılık göstermektedir (Şahlanan, 2014). Aslında alt işverenlikle ilgili yasal düzenlemelere hâkim olan temel yaklaşımın, kurumun doğrudan yasaklanması değil, kötüye kullanılmasının engellenmesi şeklinde olmalıdır (Soyer, 2013:34).

"Daha önce o işyerinde çalşstrılan kimse ile alt işveren ilişkisi kurulamaz" yasağın müeyyidesi de "... Aksi halde ve genel olarak asıl işveren alt işveren ilişkisinin muvazaal işleme dayandiğı kabul edilerek alt işverenin iş̧̧ileri başlangıçan itibaren asıl işverenin işçisi sayılarak işlem görürler..." şeklinde belirtilmiştir. Başka bir ifadeyle, daha önce asıl işverenin işçisi olarak çalışan bir kişi ile alt işverenlik ilişkisi kurulmaya çalışıldığında, kanun bu durumu muvazaalı işlem olarak değerlendirmekte; alt işverenlik ilişkisinin oluşmadığını, dolayısıyla alt işveren işçilerinin başlangıçtan itibaren asıl işverenin işçileri olarak kabul etmektedir. Alt İşverenlik Yönetmeliğinin 4/d maddesi, "alt işveren, daha önce o işyerinde çalıştırılan bir kimse olmamalıdır. Ancak daha 
önce o işyerinde çalıştırlan iş̧̧inin bilahare tüzel kişi şirketin ya da adi ortakllğın hissedarı olmasl, alt işveren ilişkisi kurmasina engel teşkil etmez." hükmüne yer vererek belirtilen yasağa esneklik getirmiştir.

\section{4. İşyerinde Yürütülen Mal veya Hizmet Üretimine İlişkin Yardımcı İşler}

İşveren tarafindan mal veya hizmet üretmek amacıyla maddî olan ve olmayan unsurlar ile iş̧̧inin birlikte örgütlendiği birime işyeri denir. İşyeri, belirli bir mal üretmek veya hizmet yürütmek için kurulur ve belirtilen mal ve hizmet üretimi, o işyerinin teknik amacını oluşturur. Söz konusu teknik amaca yönelik üretim faaliyetlerinin bir kısmı olmazsa olmazdır ve aslidir. Bir kısmı da ikinci niteliktedir ve talidir (Mollamahmutoğlu, 2004). İş Kanunu’nun 2. maddesinde yer alan “...bir işverenden, işyerinde yürüttü̆̆̈̈ mal veya hizmet üretimine ilişkin yardımcı işlerinde..." düzenlemesiyle alt işveren ilişkisinin doğabilecek alanlardan biri "yardımcı işler" olarak ortaya çıkmaktadır.

Alt işveren Yönetmeliği yardımcı işi, "işyerinde yürütülen mal veya hizmet üretimine ilişkin olmakla beraber doğrudan üretim organizasyonu içerisinde yer almayan, üretimin zorunlu bir unsuru olmayan ancak asıl iş devam ettikçe devam eden ve asıl işe bağımlı olan iş" şeklinde tanımlamıştır. Bu işlerin alt işverene verilmesinde Kanun özel bir şart aramamıştır.

Önemle belirtilmelidir ki, 1475 sayllı Kanunda belirtilen "bir işverenden belirli bir işin bir bölümünde veya eklentilerinde iş alan...” ifadesiyle, alt işverenlik kapsamı daha geniş bir hal almaktaydı. Ancak, 4857 Sayılı Kanun ile "yardımcı işin" işyerinde yürütülen mal veya hizmet üretimine yönelik olduğu vurgulanmakta; kanunun gerekçesinde de belirtildiği gibi, yürütülen asli ve yardımcı işler dışında iş alan bir işveren, örneğin bir dokuma işyerinde bir ek inşaat yapılması ya da bina onarım işini alan diğer işverenin alt işveren kapsamında nitelendirilmesi mümkün olamayacaktır. Zira söz konusu inşaat işi, işyerinde üretilen asıl iş olmadığı gibi, yardımc1 iş de değildir.

Alt işverenlik, "işyerinde yürütülen asıl işin" gerçekleşmesine yardımcı olan işler kapsamında olmalıdır. Bu ifade sınırlayıcı bir ifadedir ve herhangi bir yardımcı işi değil, sadece o işyerinde yürütülen mal ve hizmet üretimine yardımcı işi kapsamaktadır (Mollamahmutoğlu, 2004). Alt işverene verilen iş, işyerinde yürütülen mal veya hizmet üretimine ilişkin bir iş olmalı, asıl işe bağımlı ve asıl iş sürdüğü müddetçe devam eden bir iş olmalıdır. Bu durumda asıl işin üretime yardımcı olmayan işlerde asıl işverenlik alt işverenlik ilişkisi söz konusu olmayacaktır.

Asıl iş-yardımcı iş kavramlarının, işin niteliğine göre farklılık arz edebileceği gözden kaçırılmamalıdır. Yardımcı işler, genel kabulle, doğrudan üretim organizasyonu içerisinde yer almayan yükleme, boşaltma, temizlik, yemek hizmetleri, odacılık ve çay hizmetleri, personel taşıma, güvenlik ve teknik bakım gibi vb. işlerdir. Ancak, işverence yürütülen işler yemek, temizlik, personel taşıma gibi işlerden olması halinde bahsedilen iş, yardımcı iş değil, asıl iştir (Canpolat, 2010). Bu bağlamda, örneğin bir boya fabrikasında yemek işleri yardımcı işleri iken, bir lokantada yemek işi asıl iştir. Aynı şekilde temizlik işi, temizlik firmasında asıl iş iken, boya fabrikasında yardımcı iştir. 


\section{Asıl İşin Bir Bölümünde İşletmenin ve İşin Gereği İle Teknolojik Nedenlerle Uzmanlık Gerektiren İşler}

4857 Sayılı İş Kanunu, alt işveren ilişkisinin doğumu için, "asıl işin bir bölümünde işletmenin ve işin gereği ile teknolojik nedenlerle uzmanlık gerektiren işler”in varlığını aramıştır. Yönetmelik, işletmenin ve işin gereği ile teknolojik sebeplerle uzmanlık gerektiren işi, mal veya hizmet üretiminin zorunlu unsurlarından olan, işin niteliği gereği işletmenin kendi uzmanlığı dıșında ayrı bir uzmanlık gerektiren iş şeklinde açıklamıştır.

İşverenin kendi işçileri ve yönetim organizasyonu ile mal veya hizmet üretimi yapması esas olmakla birlikte asıl işin,

a) İşletmenin ve işin gereği,

b) Teknolojik sebeplerle uzmanlık gerektirmesi

şartlarının birlikte gerçekleşmesi hâlinde bölünerek alt işverene verilmesi mümkündür (Yön/11). Bu bağlamda asıl işin bir bölümünün alt işverene verilebilmesi için belirtilen iki şartın gerçekleşmesi gereklidir.

“Teknolojik nedenlerle uzmanlık gerektiren işler”, nispeten anlaşllabilir bir haldir. Ancak, "işletme ve işin gereği” ifadesi, belirsiz ve anlaşılması zor bir genişlik ve sübjektiflik belirtmektedir. Söz konusu durum, özellikle uygulamada, bir takım sıkıntıları da beraberinde getirmektedir. Alt işverenlik ilişkisinin, işletmenin ve işin gereği ile teknolojik nedenlerle uzmanlık gerektiren işlerde gerçekleştiğini, ihtilaflı hallerde, asıl işveren kanıtlamalıdır.

$\mathrm{Bu}$ noktada üzerinde durulması gereken bir konu da, "işletmenin ve işin gereği ile teknolojik nedenlerle uzmanlik gerektiren işler dişında asıl işin bölünerek alt işverenlere verilemeyecektir." düzenlemesidir. Kanunun gerekçesinde de belirtildiği gibi, "bir işyerinde asıl işveren-alt işveren ilişkisinin doğumu için, asıl işin "bir bölümünde" iş alınmasının anlamı, aynı bölümde asıl işverenin artık işçi çalıştırmayacağı, işçilerin bölünme suretiyle bir kısmının asıl işverence, diğer kısmının alt işverence yürütülmesinin” mümkün olamayacak olmasıdır. Örneğin, asıl işin bir bölümü olan kaynak işleri alt işverene verilmiş ise, kaynak işlerinin tümü alt işverene verilecek, asıl işveren kaynak işlerinin bu bölümünde kendi işçilerini çalıştıramayacaktır (Şen,2003).

\section{Alt İşveren İşçilerinin Daha Önce Asıl İşverenin İşçileri Olarak Çalışmış Olmaları Halinde Hakıarının Kısıtlanamayacağı İlkesi}

İş Kanunu, asıl işverenin işçilerinin alt işveren işçisi olarak çalıştırılmasına yönelik özel bir düzenleme getirmiştir. Kanunda "asıl işverenin işçilerinin alt işveren tarafından işe alınarak çalıştırılmaya devam ettirilmesi suretiyle hakları kısıtlanamaz" ifadesine yer verilmiştir. Uygulamada rastlanılan ve yargı kararlarına konu olan olumsuz haller Kanuna taşınmıştır. Zikredilen yasağın müeyyidesi de "alt işverenin işçileri başlangıçtan itibaren asıl işverenin işçisi sayılarak işlem” görecekleri şeklinde ortaya konulmuştur. Bu bağlamda, asıl işin bir bölümünün alt 
işverene verilmesi halinde, işçilerin özlük haklarından (yıllık izin, ihbar ve kıdem tazminatlarına ilişkin kıdem sürelerinde) herhangi bir "kısıtlama" (sınırlama, yanma) hükmü söz konusu olamayacaktır. Bu tür kısıtlamaların olması halinde, geçersizlik söz konusu olacaktır (Demir, 2003). Hakların kısıtlanması söz konusu değilse, asıl işverenin işçilerinin alt işveren tarafından işe alınarak çalıştırılmaya devam ettirilmesi mümkündür.

\section{Alt İşveren İşçilerinin Sadece Asıl İşverene Ait İşyerinde Çalıştırııması}

1475 sayılı Kanunda yer alan "iş̧̧ilerini münhasıran o işyerinde ve eklentilerinde çalıştıran" ifadesi 4857 Sayılı İş Kanunu’nda "iş̧̧ilerini sadece bu işyerinde aldiğı işte çalıştıran" şekline getirilmiştir. Anlam açısından farklı olmayan bu durum, alt işverenin iş̧̧ilerinin "sadece" asıl işverenin işyerinde çalışması gerektiğini ortaya koymaktadır. Şüphesiz, alt işveren konumundaki kişinin farklı işçi ve işyeri olabilecektir. Ancak, asıl işveren ve alt işveren ilişkisine konu olan işçiler "sadece" asıl işverenin işyerinde çalışan işçilerdir. Söz konusu düzenleme, işin doğası gereğidir. Zira alt işverenin işçilerin "sadece" asıl işverene ait işyerinde çalıştırılması halinde, asıl işverenin sorumluluğu söz konusu olacaktır.

\section{Birlikte Sorumluluk}

İşyerindeki mal/hizmet üretimini dışsallaştırmanın tipik örneklerinden biri olan alt işverenlikte, asıl işverenin kendi işyerinde kendi işçileri ile gerçekleştireceği bir üretim, başka bir işverenin iş̧̧ileri aracılığıyla yerine getirilmektedir (Güzel, 2004:38). Bu nedenle asıl işveren, alt işverenin iş̧̧ilerine karşı o işyeriyle ilgili olarak Kanundan, iş sözleşmesinden veya alt işverenin taraf olduğu toplu iş sözleşmesinden doğan yükümlülüklerinden, alt işveren ile birlikte sorumludur.

Birlikte sorumluluğun niteliği bakımından, asıl işveren ile alt işveren arasındaki sözleşmenin istisna (eser), vekâlet, kira, taşıma sözleşmeleri olması arasında bir fark bulunmamaktadır (Demir, 2003).

Asıl işverenin birlikte sorumlu bulunduğu alanlar, kanun tarafından ortaya konulmuştur. Buna göre asıl işveren, alt işverenin işçilerine karşı o işyeri ile ilgili olarak;

- İş Kanunundan,

- İşsözleşmesinden veya

- Alt işverenin taraf olduğu toplu iş sözleşmesinden doğan yükümlülüklerinden alt işveren ile birlikte sorumludur.

1475 Sayılı İş Kanununda asıl işverenin birlikte sorumluluk alanları, asıl işverenin işyeri ilgili olarak, İş Kanunu ve işs sözleşmesinden doğan yükümlülükler" olarak belirlenmekteydi. Ancak, kanunun gerekçesinde de belirtildiği gibi, yargı kararlarında ve doktrinde benimsenmiş olan alt işverenin taraf olduğu toplu iş sözleşmesinden doğan hükümlerinden de asıl işveren birlikte sorumlu hale gelmiştir. 
Birlikte sorumluluk, küçük sermaye sahibi alt işverenlerinin borçlarını yerine getirmeyecek hale düşmesi tehlikesine karşı alt işveren işçilerini korumayı amaçlamaktadır (Demircioğlu, Centel, 2012:51). Bu sorumluluk, alt işverenin iş̧̧isinin o işyeriyle ve o işyerinde çalıştığ 1 süreyle sınırlıdır (Koç, 2005:97). Birlikte sorumluluk, özellikle, işçinin özlük hakkının korunmasına yöneliktir. Buna aksine hükümler geçerli olmayacaktır.

Alt işverenin İş Kanunu'ndan doğabilecek sorumluluklarını, İş Kanunundan ve sözleşmeden kaynaklanan ücret, fazla çalışma, hafta tatili, genel ücreti, ylllık izin ücreti, ikramiye, prim, yemek ve yol yardımı, ihbar tazminatı, kıdem tazminatı, kötüniyet tazminatı, şartları oluşmuşsa iş güvencesi bağlamında boşta geçen süre ücreti, işe başlatılmama tazminatı gibi ücret ve sosyal haklara yönelik sorumluluklar şeklinde belirtmek mümkündür (TİSK, 2012:17)

\section{E. Kanuna Aykırı Kurulan Asıl-Alt İşverenlik İlişkisinin Sonuçları}

Asıl-Alt işverenlik ilişkisinde ortaya çıkan problemlerin başında, şartları oluşmadan asıl-alt işverenlik ilişkisinin kurulması gelmektedir. Bazı durumlarda teknolojik sebep olmadan asıl işler bölünerek alt işverenliğe verilmekte; bazı durumlarda ise yardımcı işlerde alt işveren ilişkisi kurulmasına rağmen alt işveren işçilerin sevk ve idaresine asıl işverenler müdahale etmektedirler. İş Kanunu’nun 2. maddesi ve bu maddeye istinaden çıarılan Alt İşverenlik Yönetmeliği, Kanuna aykırı bir şekilde kurulan asıl -alt işveren ilişkisine yönelik bir takım müeyyideler getirmiştir. Söz konusu müeyyideleri hukuki ve cezai müeyyideler olarak tasnif etmek mümkündür.

\section{Hukuki Müeyyide}

İş Kanunu, asıl işverenin işçilerinin alt işveren tarafından işe alınarak çalıştırılmaya devam ettirilmesi suretiyle haklarının kısıtlanamayacağını veya daha önce o işyerinde çalıştırılan kimse ile alt işveren ilişkisinin kurulamayacağını, aksi halde ve genel olarak asıl işveren alt işveren ilişkisinin muvazaalı işleme dayandığ 1 kabul edilerek alt işverenin iş̧̧ilerinin başlangıçtan itibaren asıl işverenin işçisi sayılarak işlem göreceğini hüküm altına almıştır (İşK/2). Çalışma ve Sosyal Güvenlik Bakanlığı İş Müfettişleri tarafından şartlar oluşmadan ve kanuna aykırı biçimde kurulan asıl-alt işveren ilişkilerine yönelik incelemeler yapılmakta ve muvazaanın tespiti halinde müfettiş raporuna itiraz edilebilmektedir. Söz konusu rapora itiraz edilmezse veya mahkeme muvazaalı işlemin tespitini onamışsa alt işverenin işçileri başlangıçtan itibaren asıl işverenin işçileri sayılmaktadır.

\section{a) Muvazaa Kavramı}

Muvazaa, tarafların üçüncü kişileri aldatmak amacıyla ve kendi gerçek iradelerine uymayan ve aralarında hüküm ve sonuç meydana getirmesini istemedikleri görünüşte bir anlaşma şeklinde tanımlanabilir. Muvazaada üçüncü kişileri aldatmak kastı bulunmaktadır ve sözleşmedeki gerçek amaç gizlenmektedir.

Alt İşveren Yönetmeliği ise muvazaảyı farklı durumları anlatacak şekilde tanımlamıştır. Buna göre muvazaa; 
- $\quad$ İşyerinde yürütülen mal veya hizmet üretimine ilişkin asıl işin bir bölümünde uzmanlık gerektirmeyen işlerin alt işverene verilmesini,

- Daha önce o işyerinde çalıştırılan kimse ile kurulan alt işverenlik ilişkisini,

- $\quad$ Asıl işveren işçilerinin alt işveren tarafından işe alınarak hakları kısıtlanmak suretiyle çalıştırılmaya devam ettirilmesini,

- Kamusal yükümlülüklerden kaçınmak veya işçilerin iş sözleşmesi, toplu iş sözleşmesi yahut çalışma mevzuatından kaynaklanan haklarını kısıtlamak ya da ortadan kaldırmak gibi tarafların gerçek iradelerini gizlemeye yönelik işlemleri,

ihtiva eden sözleşme şeklinde tanımlamıştır.

Yönetmeliğe göre, tescili yapılan işyeri için Kanuna aykırılık veya muvazaa kanaatini oluşturan delillerin bulunması hâlinde, söz konusu belgeler gerekçesi ile birlikte incelenmek üzere bölge müdürlüğü (Çalışma ve İş Kurumu İl Müdürlüğü) tarafından İş Teftiş Grup Başkanlığına intikal ettirilir.

\section{b) Muvazaanın Incelenmesinde Dikkat Edilecek Hususlar}

Alt İşverenlik Yönetmeliği muvazaaya yönelik yapılacak incelemelerde dikkat edilmesi gereken hususlar ayrıntılı olarak düzenlemiştir. Buna göre muvazaanın incelenmesinde;

a) Alt işverene verilen işin, işyerinde asıl işveren tarafından yürütülen mal veya hizmet üretimine ilişkin asıl işin yardımcı işlerinden olup olmadı̆̆ı,

b) Alt işverene verilen işin işletmenin ve işin gereği ile teknolojik nedenlerle uzmanlık gerektiren bir iş olup olmadı̆̆

c) Alt işverenin daha önce o işyerinde çalıştırılan bir kişi olup olmadığı,

ç) Alt işverenin işe uygun yeterli ekipman ile tecrübeye sahip olup olmadığı,

d) İstihdam edeceği işçilerin niteliklerinin yapılacak işe uygun olup olmadığı,

e) Alt işverene verilen işte asıl işveren adına koordinasyon ve denetimle görevlendirilenlerden başka asıl işverenin işçisinin çalışıp çalışmadığı,

f) Yapılan alt işverenlik sözleşmesinin iş hukukunun öngördüğü kamusal yükümlülüklerden kaçınmayı amaçlayıp amaçlamadığı,

g) Yapılan alt işverenlik sözleşmesinin işçilerin iş sözleşmesi, toplu iş sözleşmesi yahut mevzuattan kaynaklanan bireysel/kolektif haklarını kısıtlamaya ya da ortadan kaldırmaya yönelik yapılıp yapılmadı̆̆ı̆,

hususları göz önünde bulundurulur (Yön/12). 


\section{c) Muvazaalı Durum ve İş Mahkemesine İtiraz}

Asıl işveren-alt işveren ilişkisinin iş müfettişlerince incelenmesi sonucunda muvazaanın tespitine ilişkin gerekçeli müfettiş raporu ilgili il müdürlüğünce işverenlere tebliğ edilecektir. Bu rapora karşı tebliğ tarihinden itibaren otuz iş günü içinde işverenlerce yetkili iş mahkemesine itiraz edilebilecektir. İtiraz üzerine görülecek olan dava basit yargılama usulüne göre dört ay içinde sonuçlandırılır. Mahkemece verilen kararın temyizi hâlinde Yargıtay altı ay içinde kesin olarak karar verir. Kamu idarelerince bu raporlara karşı yetkili iş mahkemelerine itiraz edilmesi ve mahkeme kararlarına karşı diğer kanun yollarına başvurulması zorunludur.

4734 sayılı Kamu İhale Kanunu’nun Ek 8. Maddesinde yapılan değişliğe göre, 4857 sayılı Kanunun 3. Maddesinde öngörülen itiraz veya diğer kanun yollarına başvurmayan kişilere ise her türlü aylık, ödenek, zam, tazminat dâhil yapılan bir aylık net ödemelerin iki katı tutarında idari para cezası uygulanır.

\section{d) Hukuki Sonuç}

Asıl işveren-alt işveren ilişkisinin iş müfettişlerince incelenmesi sonucunda muvazaanın tespitine ilişkin gerekçeli müfettiş raporuna otuz iş günü içinde itiraz edilmemiş veya mahkeme muvazaalı işlemin tespitini onamış ise tescil işlemi iptal edilir ve alt işverenin işçileri başlangıçtan itibaren asıl işverenin işçileri sayılır.

\section{Cezai Müeyyide}

İş Kanunu'nun 98. maddesi, 3 üncü maddesinin ikinci fıkrasındaki işyerini muvazaalı olarak bildiren asıl işveren ile alt işveren veya vekillerine ayrı ayrı on bin Türk Lirası idari para cezası verilir. 2016 yılı için söz konusu ceza miktarı 17.700 TL olarak uygulanacaktır.

4734 sayılı Kamu İhale Kanunu'nun Ek 8. Maddesinde yapılan değişikliğe göre, personel çalıştırılmasına dayalı hizmet alımı ihaleleri çerçevesinde çalıştırılan personel, ihale ve sözleşme konusu iş dışında başka bir işte çalıştırılamaz ve görevlendirilemez. Bu kapsamda, personel çalıştırılmasına dayalı hizmet alımı ihalesine çıkılmaması gerektiği hâlde ihaleye çıkılması, uygun görüş alınması gereken hâllerde alınmadan ihaleye çıkılması, ihale kapsamında çalıştırılan personelin sözleşme konusu işler dışında çalıştırılması, 4857 sayılı Kanunun 2. maddesinin yedinci fıkrası hükmüne aykırılık teşkil edecek şekilde işlem ve eylemler yapılması nedeniyle idare aleyhine zarar ortaya çıkması hâlinde, oluşan bu zararlar, bu zarara neden olduğu tespit edilenlere rücu edilmek suretiyle tahsil edilir. Ayrıca, bu kişiler hakkında uygulanacak ceza ve disiplin hükümleri saklı kalmak üzere, bu kişilere her türlü aylık, ödenek, zam, tazminat dâhil yapılan bir aylık net ödemelerin beș katı tutarında idari para cezası uygulanır. 


\section{TÜRKIYY'DE ALT IŞVERENLIĞIN MEVCUT DURUMU, SORUNLARI VE ÇÖZÜM ÖNERILERI}

\section{A. Türkiye'de Alt İşverenliğin Tarihi Gelişimi ve Mevcut Durumu \\ I. Türkiye'de Alt İşverenliğin Tarihi Gelişimi}

Türkiye'de alt işverenlik kurumuna yönelik ilk düzenlemeler 1936 tarihli 3008 sayılı ilk İş Kanunu’na kadar geriye gitmektedir. 3008 Sayılı İş Kanunu’nun 1. Maddesinde “iş̧̧iler, doğrudan doğruya işveren veya vekili tarafından olmayıp da üçüncü bir şahsın aracılığı ile işe girmiş ve bu üçüncü şahıs ile mukavele akdetmiş olsalar bile mukavele şartlarından asıl işveren mesuldür." hükmüne yer vermiştir. Alt işverenlik, ilk çıktığından beri tartışmalara neden olmuştur. Zamanla çeşitli değişiklilerden geçerek, günümüze kadar gelen alt işverenlik, günümüzde dahi tartışmaların odağındadır (Görmüş, 2013).

1967 tarihli 931 sayılı İş Kanunu ile asıl işverenin sorumlu tutulması için alt işveren işçilerinin "münhasıran" çalıştırılmaları zorunlu tutulmuştur (TİSK, 2012:8). 931 sayılı İş Kanunu Anayasa Mahkemesinin 14.05.1970 tarih ve E.1970/40, K.1970/26 sayll kararı ile iptal edilmesi üzerine 1475 sayılı İş Kanunu çıkarılmıştır (Kurt, 2006:9). 1971 tarihli 1475 sayılı İş Kanununda alt işverenlik "bir işverenden belli bir işin bir bölümünde veya eklentilerinde iş alan ve iş̧̧ileri münhasıran o işyerinde çalıştıran diğer bir işverenin kendi işçilerine karşı o işyeri ile ilgili ve bu kanundan doğan yüklemlerinden asıl işveren de birlikte sorumludur." şeklinde düzenlenmiştir. 2003 tarihli 4857 sayılı İş Kanunu ile 1475 sayılı İş Kanununun 14. maddesi dışındaki diğer maddeleri yürürlükten kaldırılmıștır.

Türkiye'de özellikle 1980'li yıllardan itibaren çalışma hayatındaki girift ilişkiler ile uzmanlık gerektiren işlerin varlığı, mevcut çalışma biçimlerini değiştirmiş, buna bağlı olarak da yeni çalışma biçimlerinin hukuki alt yapılarının hazırlanması ihtiyacı doğmuştur. Bu bağlamda 4857 sayılı İş Kanunuyla alt işverenlik yeni bir hüviyetle ele alınmıştır. Konuya ilişkin olarak İş Kanununun gerekçesinde aşağıdaki hususlara yer verilmiştir. İşyerinde alt işverene iş verilmesi çalı̧̧ma hayatının gereksinimlerinden biri ve hukuki dayanakları bulunan bir ilişki olduğu bilinen bir gerçektir. Ancak, 1980'li yllardan sonra ekonomik şartların etkisiyle de olsa alt işverenlere işlerin verilmesinde sayısal artışlar olmuş ve bunun sonucu iş̧̧ilerin bireysel ve kolektif haklarımın sinırlandırlması, kullanılamaz hale getirilmesinin yaygın örneklerinin bulunduğu yargyya intikal eden uyuşmazlıklarla da doğrulanmıştır. Yargıtay’n tespitlerinde muvazaalı işlemlerin belirli ölçütlerle açıkça ortaya konulması ve hukuki sonuçları, önemli bir fren oluşturmuşsa da; yüksek mahkemenin görüşleri de dikkate alınarak asıl işveren-alt işveren ilişkisinin kötüye kullanılmasına firsat yaratmamak üzere konunun madde hükümleri arasına alınarak düzenlenmesi uygun görülmüştür.

\section{Türkiye'de Alt İşverenliğin Mevcut Durumu}

Türkiye'de alt işveren tarafından istihdam edilen işçi sayısına yönelik sağlıklı bilgilere ulaşılamamaktadır. Alt işveren işçilerine ilişkin farklı veriler söz konusudur. TBMM’de verilen 
soru önergesine üzerine Çalışma ve Sosyal Güvenlik Bakanlığı tarafından verilen cevapta 2014 sonu itibariyle Türkiyedeki alt işveren işçi sayısı 1 milyon 482 bin 690 olarak açıklanmıştır (ÇSGB, 2015). Aynı dönemde (Aralık/2014) SGK kapsamında 4/a sigortalı sayısının 13.240.122 (SGK, 2014) kişi olduğu dikkate alındığında alt işveren işçinin 4/I-a sigortalı işçi sayısına oranı yaklaşık \%11 olarak ortaya çıkmaktadır.

Türkiye'de son yıllarda alt işveren tarafından istihdam edilen işçi sayısında artış gözlenmektedir. 2004 yılında kamu ve özel alt işveren işçi sayısı 181.715 iken 2013 yılında bu sayı 1.220.185’e ulaşmıştır (ÇSGB, 2014). İlgili dönemde alt işveren işçi sayısı yaklaşık 7 (6,7) kat artmıştır.

Tablo I: Türkiye’de Kamu ve Özel Sektörde Çalışan Alt İşveren İşçi Sayıları

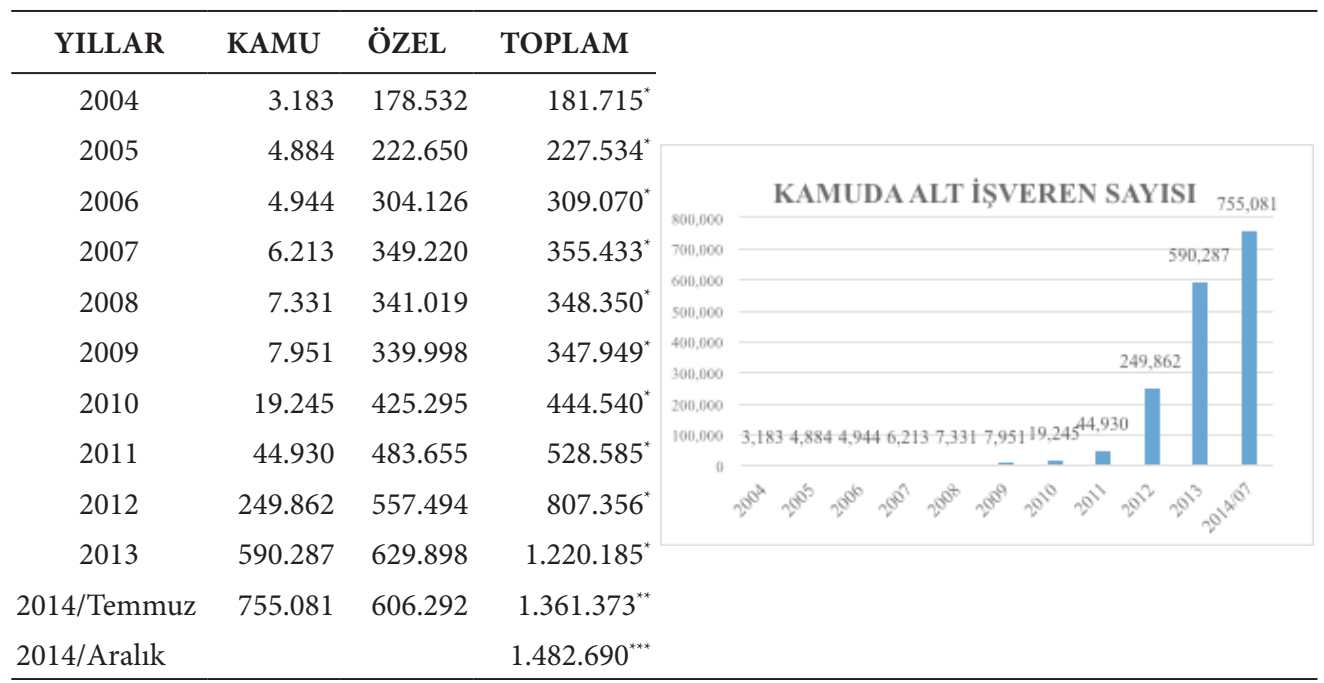

* ÇSGB, 22.10.2014, http://www2.tbmm.gov.tr/d24/7/7-44973sgc.pdf

** Milliyet Gazetesi, “1.36 milyon taşeron çalışıyor.”, 26.11.2014, http://www.milliyet.com.tr/1-36-milyontaseron-calisiyor-gundem-1975085/

*ै** ÇGB, 01.05.2015, http://www2.tbmm.gov.tr/d24/7/7-43275sgc.pdf

Kamu kesiminde işlerinin bir bölümünün alt işverenlere devredilmesiyle alt işverene bağlı çalışan işçi sayısında önemli ölçüde artışlar gerçekleşmiştir. Kamu kurum ve kuruşlarında alt işverene bağlı çalışan işçi sayısındaki artış, iş uyuşmazlıklarında da paralel şekilde artışa sebep olmuştur (Görmüş, 2013).

Mayıs 2015 döneminde kamuda yaklaşık 770 bin taşeron işçisinin olduğuna ilişkin bilgiler medyaya yansımıştır. (Memur Haber, 2015). Aynı dönemde kamuda (alt işverenler işçileri olarak istihdam edilenler hariç) farklı statülerde çalışan kişi sayısı 3.256.886 (DPB, 2015) olarak belirtilmektedir. 
Tablo 2: Kamu Personeli İstihdam Sayıları (Mayıs/20I5)

\begin{tabular}{ccccccccc}
\hline \multirow{2}{*}{ Memur } & $\begin{array}{c}\text { Hakimlik } \\
\text { Savcılık }\end{array}$ & $\begin{array}{c}\text { Öğretim } \\
\text { Elemanları }\end{array}$ & $\begin{array}{c}\text { Sözleşmeli } \\
\text { Personel }\end{array}$ & İşçi & $\begin{array}{c}\text { Geçici } \\
\text { Personel }\end{array}$ & $\begin{array}{c}\text { Asker } \\
\text { Sayılarıl }\end{array}$ & $\begin{array}{c}\text { Hükümlere } \\
\text { Tabii } \\
\text { Personel }\left(^{*}\right)\end{array}$ & Toplam \\
\hline 2.418 .781 & 15.908 & 125.355 & 107.913 & 280.939 & 22.941 & 223.566 & 61.483 & 3.256 .886 \\
& & 2.971 .837 & & & 285,049 & \\
\hline
\end{tabular}

1-) MİT Müsteşarlı̆̆ı, kadro ve pozisyonları bu sayılara dahil değildir.

2-) (*) Kamu Bankaları (T.C. Ziraat Bankası A.Ş, Merkez Bankası, Türkiye Halk Bankası A.Ş. Vakıflar Bankası T.A.O)

Devlet Personele Başkanlığı, 2015, http://www.dpb.gov.tr/F/Root/dosyalar/istatistikler/kamu_per istatistikleri/mayis2015/1 kamuPersonelistihdamRakamlar.pdf

Çalışma ve Sosyal Güvenlik Bakanlığının 01.11.2012 tarihli "Alt İşverenlik Uygulaması, Yapısı Gereği Örgütlenmeyi ve Toplu İş Sözleşmesinden Yararlanmayı İmkânsızlaştırıyor” haberinde Çalışma ve Sosyal Güvenlik Bakanlığıının raporuna atfen kamuda 585 bin 788 ve özel sektörde 419 bin 466 olmak üzere toplam 1 milyon 5 bin 254 kişi alt işverenlerde çalışmaktadır. Raporda taşeron işçiliğin en yaygın olduğu sektörler 417 bin kişi ile temizlik ve 318 bin kişi ile inşaat sektörleri olarak belirtilmektedir (ÇSGB, 2012). Raporda hizmet alımının en yaygın olduğu kamu kurumları, yüzde 36 ile belediyeler, yüzde 14 ile KİT'ler ve yüzde 4 ile yükseköğretim kurumları olarak aktarılmaktadır (ÇSGB, 2012). Başka bir ifadeyle, taşeron uygulaması hemen hemen bütün sektörlerde görülmekle birlikte, belediye ve bağlı şirketleri ile sağlık sektöründe ciddi bir yaygınlık kazandığı söylenebilir (Yazıcı, 2014:1).

Tablo 3: Kamuda ve Özel Sektörde Çalışan İşçi Sayısı (20I2)

\begin{tabular}{lrlr}
\hline Kamu Sektör & $\begin{array}{c}\text { Alt İşveren } \\
\text { İşçi Sayısı }\end{array}$ & Özel Sektör & $\begin{array}{c}\text { Alt İşveren } \\
\text { İşçi Sayıs }\end{array}$ \\
\hline Sağlık & 16.184 & İdari ve destek hizmetleri & 4.146 \\
Temizlik & 471.442 & Ulaştırma ve depolama & 10.347 \\
Güvenlik & 117.541 & Madencilik, taşocakçllığ & 12.606 \\
Dağıtım & 34.621 & İmalat & 63.849 \\
Toplam (Raporda belirtilen) & 585.788 & İnşaat & 318.087 \\
& & Diğer & 10.431 \\
Toplam (Hesaplanan) & 639.788 & Toplam & 419.466 \\
ÇSGB, 2012, http://www. & & & \\
csgb.gov.tr/csgbPortal/csgb. & & & \\
portal?page=haber\&id=basin491 & & & \\
\hline
\end{tabular}




\section{B. Türkiye'de Alt İşverenliğin Sorunları ve Çözüm Önerileri}

\section{Türkiye'de Alt İşverenliğin Sorunları}

Alt işverenlik konusunda ana hatlarıyla iki temel yaklaşımdan bahsedilebilir. Birinci yaklaşıma göre alt işverenlik özellikle 1980’li yıllardan sonra ortaya çıkan ekonomik ve teknolojik değişmelerin ortaya çıkardığı amansız küresel rekabet altında kalan işletmelerin varlıklarını sürdürebilmeleri için bir gereklilik sonucu ortaya çıkmıştır. Diğer yaklaşımda ise küreselleşmenin getirdiği atmosferde alt işverenlik, ucuz ve sendikasız işgücü oluşturma gayesiyle oluşturulan ve çalışanların kazanımlarını ortadan kaldıran bir çalışma modeli olarak ortaya çıkmıştır. Her iki görüşün de ortaya koyduğu tezler ve gerçeklikler mevcuttur.

\section{a) Alt işverenliğin Gerekliliği}

Ekonomik ve teknolojik gelişmeler, 1980’li yıllardan itibaren işletmeleri mal üretimine veya hizmet sunumuna ilişkin organizasyonlarında yeni yöntem arayışlarına sevk etmiş, küreselleşme süreci ile birlikte işletmeler, ekonomik kriz ve küresel pazarda rekabet şartlarına uyumlu stratejiler takip etmeye başlamışlardır (Güzel, 2004:33). Küresel ekonomik gelişmeler, işletmeleri gittikçe şiddetlenen rekabete sürüklediğinden firmalar, tüketicinin talep ettiği mal veya hizmetleri hem müşteri memnuniyetini karşılayacak derecede kaliteli hem de onların satın alabilecekleri ölçüde makul bir fiyatla pazara sunmak zorunda kalmışlardır. Bu bağlamda küresel rekabet, kamu hizmetleri dahil olmak üzere bütün işletmeleri karşı karşıya getirmiştir (Eryiğit, 2010). Gelişen teknoloji ve uluslararası ticaretin önündeki engellerin kaldırılmasıyla uluslararası alana taşınan rekabet, işletmeleri, hem bölgesel, hem ulusal ve hem de uluslararası piyasada yüksek kaliteli ve düşük maliyetli üretim yöntemlerini bulup geliştirmelerini zorunlu kılmıştır (Görmüş, 2013).

Piyasalarda artan uzmanlık alt ișverenliği gerekli kılmaktadır. Yeni teknolojiler ve küreselleşme, piyasalarda uzmanlık ihyacını artırmıştır. Alt işverenlik ile işletmeler yaptıkları bazı işleri uzman kurumlara bırakmaktadırlar. Bu yöntemle maliyet ve zaman tasarrufu sağlanarak üretimde etkinlik ve kalite artışı gerçekleştirilmekte, dolayısıyla işletmeler bütün enerjilerini uzman oldukları konulara yoğunlaştırarak verimlik ve rekabet güçlerini artırmaktadırlar. Böylece alt işverenlik, işyerlerinin "en başarılı oldukları işe odaklanma” fırsatını sağlamaktadır (TİSK, 2012:5). Türkiye’de de kamu işyerleri bazı hizmetlerini uzmanlaşmış olan firmalardan satın almayı verimlilik açısından önemsemektedirler (Yüce,2010).

Kamu ekonomisinin küçülmesi kamu kurumların bazı faaliyet alanlarını terk etmesine sebep olmuștur. Küreselleşmenin getirdiği önemli bir sonuç da, kamu ekonomisinin küçülerek bazı faaliyet alanlarını terk etmesidir. Bu nedenle kamu bazı alanlarda teknolojiyi yenileyememekte ve istihdam oluşturamamaktadır. Bundan dolayı kamu, bazı hizmetleri doğrudan kendi çalışılanları ile değil; dışarıdan hizmet satın almak suretiyle yerine getirmektedir (Yüce, 2010).

Artan rekabet, işletmeleri en verimli üretim şekillerini yapmaya zorlamaktadır. Alt işverenlik kurumu, işletmelerin kendi asıl işlerine odaklanarak rekabet yapabilmelerine imkân sağlamaktadır. 
Yüksek maliyetlerin varlğ̆ı alt ișverenliği gerekli kılmaktadır. Türkiye'de birden fazla emek piyasası söz konusudur. Kamu emek piyasasında ücretler nispi olarak daha yüksek olduğundan bazı hizmetlerin dışarıdan sağlanması daha ucuza mal olabilmektedir (Yüce, 2010).

İktisadi ve sosyal bir takım faktörlerden dolayı ortaya çıkan kamu alt işverenliği, özellikle çalışanlara yönelik koruma mekanizmalarını zayıflattığından iş hukuku ile karşı karşıya gelmektedir (Yüce, 2010). Önemle belirtilmelidir ki, sadece Türkiye’ye özgü bir uygulama olmayan alt işverenlik, bütün dünyada yaygınlaşan bir üretim yöntemi haline dönüşmüştür. Uluslararası boyutlu rekabetin varlığı, bu durumun devam edeceğine işaret etmektedir (TİSK, 2012:5).

\section{b) Alt işverenliğin Olumsuz Sonuçları}

1980'li ylllarda bütün dünyada ortaya çıan ekonomik, teknik ve sosyal gelişmeler Türkiye’de de etkisini göstermiştir. Türkiyede bu dönemde uygulanmaya başlayan neo-liberal ekonomik politikalarının etkisiyle bazı kesimlerce alt işverenlik ucuz ve sendikasız işgücü kullanmanın en önemli araçlarından biri olarak görülmüş ve uygulanmıştır (Şen, 2006:81). Farklı nedenlerden dolayı ortaya çıkan alt işverenlik uygulamasının temel nedenlerinin başında maliyetlerin özellikle de işgücü maliyetinin düşürülmesi gelmektedir (A. Çelik,2014).

Bazı durumlarda taşeronlaşma; sendikasızlığa, sigortasızlığa, hatta kimi zaman asgarî ücretin bile altında ücret ödenmesi suretiyle işçilik maliyetlerinin düşürülmesine sebep olmakta; işçi haklarına saygıll, sendikalı, sigortalı, toplu iş sözleşmeli iş̧̧i çalıştıran işverenleri de haksız rekabete sevk etmektedir (Şakar, 2010). Benzeri şekilde taşeron çalışanları yüksek iş değiş̧irme hızıyla, düşük ücretlerle, ağır çalışma şartlarıyla, önemli sosyal hak kayıplarıyla, düşük sosyal güvence ve iş sağllğı ve iş güvenliğiyle karşı karşıya kalmaktadırlar (Özdemir, 2010:42). Taşeron işçiliğine yönelik yapılan bir araştırmada, Türkiyede taşeronluğun adeta işçileri güvencesiz çalışmaya mecbur etmek üzere tasarlanan bir çalışma modeli olduğuna vurgu yapılmıştır (Yazıcı, 2014:26).

İşgücü piyasasının parçalanması esasına dayanan ve yeni bir istihdam modeline dönüşen alt işveren uygulaması, işin sevk ve yönetiminde kolaylık ve maliyette ucuzlukla birlikte sendika ve toplu pazarlık hakkını ortadan kaldırmanın etkili bir aracına dönüşmüştür (Özveri, 2008: 115119)

Çalışma ve Sosyal Güvenlik Bakanlığının 01.11.2012 tarihli "Alt İșverenlik Uygulaması, Yapısı Gereği Örgütlenmeyi ve Toplu İş Sözleşmesinden Yararlanmayı İmkânsızlaştırıyor” haberinde Çalışma ve Sosyal Güvenlik Bakanlığııın raporuna atfen özelikle alt işveren uygulamasının getirdiği olumsuzlukları özetle şu şekilde belirtilmiştir. Alt işverenlik uygulaması, örgütlenmeyi imkânsızlaştırmaktadır. Alt işverenlikilişkisi, işçilerin iş̧üvencesi hükümlerinden yararlanmasını engellemek amacıyla İş Kanunu’nda belirlenen 30 işçi sayısının altına düşürmek için kullanılmaktadır. Alt işverenlik uygulaması kapsamında çalışan işçilerin örgütlenmeleri ve kendi işverenleri ile toplu iş sözleşmesi akdetmeleri önünde yasal hiçbir engel bulunmamasına rağmen alt işverenlik uygulaması yapısı gereği örgütlenmeyi ve toplu iş sözleşmesinden yararlanmayı 
zorlaştırmaktadır. Alt işverenler, ekonomik açıdan zayıf olmaları nedeniyle iş sağlı̆̆ı ve güvenliği tedbirlerinin alınmasını asıl işverenden beklemektedirler. Alt işverenlik iş kazası ve meslek hastalıklarının oluşmasını önleyici tedbirlere ve eğitimlere gereken önemi vermemektedirler. Alt işveren işçileri asıl işverenin emir ve talimatları doğrultusunda çalıştııılmaktadır (ÇSGB, 2012).

CHP, TBMM Plan ve Bütçe Komisyonu 2015 Yllı Merkezi Yönetim Bütçe Kanunu Tasarısı Raporunda Kamu Personel Politikalarında Taşeronlaşma başlığıla kamuda bir model haline dönüşen alt işverenliğe ilişkin olarak özetle, şu hususlara değinmiştir: Kamu personel sisteminin dönüştürülme çabaları yaygınlaşmaktadır. Kamu personel sistemine yönelik dönüştürme çabalarının başında memur istihdamının alan itibariyle daraltılması gelmektedir. Özelleștirmetaşeronlaştırma yoluyla emek maliyetlerine doğrudan "siyasi" müdahale söz konusu olmaktadır. Memurluk, kadro esasına dayanan ve kamu görevinin objektif ölçütlerle yerine getirilmesi amaçları ile örgütlenen, güvenceli bir istihdam biçimidir ve genel idare esaslarına göre yürütülen asli ve sürekli görevlerin başka istihdam şekilleri tarafından yerine getirilemeyecektir. Memurlar tarafından yürütülmesi öngörülen hizmetlerin "hizmet satın alınması" yoluyla taşeronlaştırılması da doğru bir uygulama şekli değildir. Kamuda, taşeron işçiler ağırlıklı olarak başta temizlik işleri olmak üzere yardımcı hizmetlerde, sağlık hizmetleri ve yardımcı sağlık hizmetlerinde, yerel yönetim hizmetlerinde ve güvenlik hizmetlerinde çalıştırılmaktadırlar. Kamu yöneticileri hem mali hem de istihdam imkânlarını rahatça yönettiklerinden taşeronluğu tercih etmektedir. Taşeron şirketlerde sendikal örgütlenme zorluk bulunmakta ve taşeron işçilerin iş güvencesi olmadığından sendikaya üye olmaları ya da faaliyetlerine katılmaları durumunda derhal sözleşmeleri feshedilmektedir (CHP, 2014:358-359).

Kalkınma Bakanlığı, İstihdam ve Çalışma Hayatı, Özel İhtisas Komisyonu Raporunda, alt işverenlik konusunda uygulamada karşılaşılan başlıca sorunlar özetle, şu şekilde ifade edilmektedir. Alt işverenlik uygulaması kapsamında sürekli alt işverenin değişmesi işçilerin yıllık ücretli izin ve kıdem tazminatı gibi kıdeme bağlı yasal haklarından yararlanamamasına ve ücretlerini tam ve düzenli almamasına sebep olmaktadır. Söz konusu sorun, özellikle 10.09.2014 tarihli 6552 sayılı kanunla çözülmeye çalışılmıştır. Ylllık izne ilişkin olarak getirilen güvenceye göre, alt işveren işçilerinden, alt işvereni değiştiği hâlde aynı işyerinde çalışmaya devam edenlerin yıllık ücretli izin süresi, aynı işyerinde çalıştıkları süreler dikkate alınarak hesaplanır. Asıl işveren, alt işveren tarafından çalıştırılan işçilerin hak kazandıkları yıllık ücretli izin sürelerinin kullanılıp kullanılmadığını kontrol etmek ve ilgili yıl içinde kullanılmasını sağlamakla yükümlüdür (4857/56).

Kıdem tazminatına yönelik olarak getirilen güvenceye göre ise, personel çalıştırılmasına dayalı hizmet alımlarında alt işverenler tarafından çalıştırılan iş̧̧ilerin kıdem tazminatları alt işverenlerinin değişip değişmediğine bakılmaksızın aralıksız olarak aynı kamu kurum veya kuruluşuna ait işyerlerinde çalışmış olanların bu şekilde çalışmış oldukları sürelere ilişkin kıdem tazminatına esas hizmet süreleri, aynı kamu kurum veya kuruluşuna ait işyerlerinde geçen toplam çalışma süreleri esas alınarak tespit olunur. Bunlardan son alt işverenleri ile yapılmış olan iş sözleşmeleri 1475 sayılı İş Kanununun 14 üncü maddesine göre kıdem tazminatı ödenmesini 
gerektirecek şekilde sona ermiş olanların kıdem tazminatları ilgili kamu kurum veya kuruluşları tarafından işçinin banka hesabına yatırılmak suretiyle ödenir. Aynı alt işveren tarafından ve aynı iş sözleşmesi çerçevesinde farklı kamu kurum veya kuruluşlarında çalıştıılmış olan işçilerden iş sözleşmeleri 1475 sayılı İş Kanununun 14 üncü maddesine göre kıdem tazminatı ödenmesini gerektirecek şekilde sona ermiş olanlara, 4734 sayılı Kanunun 62. maddesinin birinci fikrasının (e) bendi kapsamında farklı kamu kurum ve kuruluşuna ait işyerlerinde geçen hizmet sürelerinin toplamı esas alınarak çalıştırıldığı son kamu kurum veya kuruluşu tarafından işçinin banka hesabına yatırılmak suretiyle ödenir.

Alt işverenlik uygulaması kapsamında niteliği gereği sürekli işlerde çalışan işçiler dahi kısa süreli istihdam edilmekte ve bu uygulama iş̧̧ilerin iş güvencesi hükümlerinden yararlanmasına engel olmaktadır. Asıl işveren - alt işveren ilişkisinin kurulma şartlarının müphem olmasını muvazaaya neden olabilmektedir. İş Kanununun 2'nci maddesinde kamu kuruşları için getirilen ayrık düzenlemeler uygulamada ikilik ve ayrıcalığa sebep olmaktadır. Muvazaanın tespitine bağlı olarak yargı makamları tarafından hizmet alımıyla çalışan işçilerin başlangıçtan itibaren kamu iş̧̧isi olduğuna karar verilmesi kamu bütçesine önemli bir yük getirmektedir (Kalkınma Bak. 2010:69-70).

Kamu ve özel sektör işyerleri açısından ciddi uyuşmazlıklara sebep olan asıl-alt işverenlik, çalışma hayatının temel tartışma alanlarından birini oluşturmaktadır (TİSK, 2012:5).

\section{Türkiye'de Alt İşverenlik Sorununa Yönelik Çözüm Önerileri}

Alt işverenlik konusunda ana hatlarıyla iki temel yaklaşım gündeme getirilebilir. Söz konusu yaklaşımlar alt işverenliğe bakışta, sorunu algılama ve çözüm önerilerinde de doğal olarak farklı yaklaşım göstermektedirler. Birinci yaklaşıma göre alt işverenlik özellikle 1980’li yıllardan sonra ortaya çıkan ekonomik ve teknolojik değişmelerin ortaya çıkardığı amansız küresel rekabet altında kalan işletmelerin varlıklarını sürdürebilmeleri için bir gereklilik olduğundan İş Kanununun temel felsefesinde de bulunan güvence-esneklik düzleminde piyasa şartları dikkate alınarak alt işverenliğe ilişkin katı hükümler kaldırılmalı veya esnetilmelidir. İkinci yaklaşımda ise alt işverenlik ucuz ve sendikasız işgücü oluşturma gayesiyle oluşturulan ve çalışanların kazanımlarını ortadan kaldıran bir çalışma modeli olduğundan mevcut alt işverenlik uygulamasının İş Kanununun temel yaklaşımı olan iş̧̧inin korunması ilkesinden hareketle alt işverenlik uygulaması sonlandırılmalıdır. Ancak bir üçüncü yaklaşım olarak çalışanların haklarını garantiye alan teknolojinin ve işyeri ihtiyaçları doğrultusunda mevcut yapıdaki olumsuzlukları da ortadan kaldıran bir alt işverenlik mekanizması geliştirilmelidir.

Öncelikle belirtilmelidir ki, mevcut alt işverenlik uygulaması tarafları memnun etmemektedir. Yeterince esneklik getirilmediği için eleştirilen alt işverenlik aynı zamanda örgütlenmeye engel olduğu ve hak kayıplarının yaşanmasına sebep olduğu gerekçeleriyle de tenkit edilmektedir. $\mathrm{Bu}$ yüzden özellikle kamuda, bir istihdam şekline dönen alt işverenlik uygulamasının acilen gözden 
geçirilmesi ve yaygın bir kamu çalıştırma modeli olmayacak şekilde yeniden düzenlenmesi gereklidir (Kalkınma Bak. 2010:118). Taşeron işçiliğine yönelik yapılan bir araştırmada da verilerin taşeronluk sisteminin tamamen tasfiye edilmesi veya yapısal bir değişime tâbi tutulması gerekliliğini ortaya koyduğu belirtilmiştir (Erdinç, 2014:23).

Alt işverenlik hususunda yeni yasal düzenlemelere ihtiyaç bulunmaktadır. Asıl işveren-alt işveren ilişkisinin ortaya çıkmasına yol açan (meşru) olgularla uyumlu, bu olguların ortaya çıkarttığ ihtiyaçları karşılamaya elverişli ve daha esnek bir model kurulması gereklidir. Alt işverenliğe ilişkin yapılacak düzenlemede, koruma fikrini göz ardı etmeyen ve özellikle, işyerlerinin sendikasızlaştırılmasına engel olmayacak bir muhtevada olması gerekmektedir (Soyer, 2013:63). Başka bir ifadeyle, alt işverenlik uygulamasında teknolojik veya işletme gerekliliği ile çalışanların sosyal haklarının korunması ilkelerinin birlikte değerlendirildiği bir sistemin oluşturulması gereklidir (Kalkınma Bak. 2010:70)

Kamuda bir tür istihdam şekli haline gelen alt işverenlikte, örgütlenme ve kıdem tazminatı olmak üzere alt işveren işçilerinin çalışma şartlarının iyileştirilmesi için sorunların çözülmesine yönelik düzenlemelerin yapılması gereklidir (Kalkınma Bak. 2010:69-70). Bu yüzden alt işverenin kamu ve özel sektör işletmelerindeki ihtiyaç ve yaygın konumu da dikkate alınarak her iki kesim için de geçerli ortak kurallarla düzenlenmesi gereklidir (TİSK, 2012:7-8).

Esasen, alt işverenliğin kötü niyetli ve istismara neden olan uygulamalarının önlenmesi için sosyal tarafların katılımı ile yeni mekanizmalar geliştirilmelidir (TİSK,2012:7-8).

\section{a) Siyasi Partilerin Seçim Beyannamelerinde Alt İşverenlik}

Kamuda alt işverenlik, siyasi partilerin son dönem seçim beyannamelerinin (2015) önemli bir gündem maddesini oluşturmuş ve alt işveren çalışanlarına yönelik çeşitli çözüm önerileri getirilmiştir. Ak Parti, hükümetleri döneminde yapılan icraatlara atıf yaparak kamuda asıl işlerde istihdam edilen alt işveren iş̧̧ilerinin kamuda kadroya alınmasına yönelik düzenlemeleri hedeflerken, muhalefet partileri ise kamuda çalışan bütün alt işveren işçilerinin kadroya alınacağını taahhüt etmiştir. Siyasi partilerin, kamuda istihdam edilen alt işveren işçilerine yönelik seçim beyannamelerine yansımış olan vaatleri aşağıda özetlenmiştir.

Ak Parti seçim beyannamesinde (Ak Parti, 2015:108,154) 2014 yllında kamu işyerlerinde çalışan alt işveren iş̧̧ilerine; taraf olunan toplu iş sözleşmesinden yararlanma, kıdem tazminatını doğrudan ilgili kamu kurumundan alma imkânının sağlandığı ifade edilmiştir. Tüm alt işveren işçilerinin ücretlerinin ödenmesinin ve ylllık ücretli izinlerini kullanmalarının garanti altına alındığı belirtilmiştir. Ayrıca, kamu ve özel sektörde alt işverenlerin ve alt işveren işçi sayılarının tespit edilmesinin ve güncel olarak sağlıklı bir şekilde takip edilmesinin sağlanacağı vaat edilmiştir. Ak Parti, özetle, geçmiş yıllarda yapılan icraatlarını sıralamış ve alt işveren işçilerin sayılarının sağlıklı tespitinin yapılacağını taahhüt etmiştir.

CHP seçim beyannamesinde (CHP, 2015:81,95) taşeronlaşmanın sona erdirilmesi için kamu kurumlarından başlayarak etkili bir eylem planının uygulanacağı, kamuda taşeron işçiliğine, 
alt-işveren ve rödovans uygulamasına, özel kesime de örnek olacak biçimde son verileceği, kamu çalışanlarının farklı statülerde istihdamından dolayı özlük haklarında yaşamış oldukları kayıplarının telafi edileceği ifade edilmiştir. Ayrıca, kömür işletmeciliğinde kamuyu etkin kılacak, sektörü Türkiye Kömür İşletmeleri (TKİ) eliyle yeniden yapılandıracağı ve sektörde taşeron aracilı̆̆ıla faaliyet gösterilmesine kesinlikle izin verilmeyeceği vaat edilmiştir. CHP, özetle, kamuda taşeron iş̧̧iliğine ve rödovans uygulamasına son verileceğini taahhüt etmiştir.

MHP seçim beyannamesinde (MHP,2015:91,92,193) kamuda çalışan taşeron işçilerin, 4/C’liler, vekil, sözleşmeli ve geçici statüde çalışanların kadroya geçirileceği taahhüt edilmiştir. Ayrıca, alt işveren (taşeron) iş̧̧ilerinin artan sorunlarının çözüme kavuşturulacağı, çalışma şartları ve ücretlerinin acilen iyileştirileceği, iş güvencesi, yıllık ücretli izin, fazla mesai ücreti, kıdem tazminatı gibi haklarının güvence altına alınacağı, devletin asli ve sürekli hizmetlerinde çalıştırılan taşeron işçilerine kadro verileceği vaat edilmiştir. MHP, özetle, kamuda alt işveren işçilerin kadroya geçirileceğini, özlük haklarında iyileştirilmeler yapılacağını taahhüt etmiştir.

HDP seçim beyannamesinde (HDP,2015:35-38) taşeronluk sistemi kademeli olarak ortadan kaldırılacağı, ilk etapta kamuda taşeron çalışanlar kadrolu çalışan haline getirileceği, taşeron çalışılan döneme ait kıdem tazminatları ödeneceği, özel sektörde asıl işveren, alt işverenlerle birlikte çalışana karşı eşit ve aynı derecede sorumlu olacağı, özelleştirme, taşeronlaştırma ve rödovans uygulamasına son verileceği, kamu kesimindeki istihdam rejimi değiştirileceği, sözleşmeli, taşeron vb. farklı statülerdeki güvencesiz çalışmaya son verileceği taahhüt edilmiştir. Ayrıca, kamu hizmetlerinin bütününde kadrolu ve güvenceli istihdam politikalarının uygulanacağı, taşeron sisteminin varlığına son verinceye kadar, her hangi bir iş kazasında ana firmayı da sorumlu kılacak düzenlemeler yapılacağı vaat edilmiştir. HDP, özetle, kamuda alt işveren işçilerinin kadroya alınacağını ve taşeron çalışılan döneme ait kıdem tazminatlarının ödeneceğini taahhüt etmiştir.

Siyasi partilerin seçim beyannamelerinde alt işveren işçilerine yönelik problemleri belirtilmiş, özellikle kamuda alt işveren işçilerin kadroya alınması çözüm önerisi olarak sunulmuştur.

\section{b) 64. Hükümetin Kamudaki Alt İşveren Çalışanlarına Yönelik Düzenlemesi}

64. Hükümetin 2016 Yllı Eylem Planında (Başbakanlık, 2015:12) asıl-alt işverenlik çerçevesinde asıl işlerde çalışanların kamuda istihdam edilmesine yönelik bir düzenlemenin yapılacağı belirtilmiş, daha sonra sadece asıl işlerde çalışan alt işveren işçilerinin değil; yardımcı işlerde çalışan alt işveren işçilerinin de kamuda kadroya geçirileceğine ilişkin açıklamalar yapılmıştır. Konuya ilişkin çalışmaların devam ettiği kamuoyuna yansımıştır. Kamuda istihdam edilen alt işveren işçilerinin kadroya alınmasına yönelik olarak, Ak Parti Ekonomi İşleri Başkanlığı tarafından hazırlanan ekonomik bültende aşağıdaki hususlara yer verilmiştir (Ak Parti, 2016:1-3).

Kamu işyerlerindeki personel çalıştırılmasına dayalı hizmet alım işlerinde çalışan işçilerin kadroya alınması ve hem asıl işlerde hem de yardımcı işlerde çalışan yaklaşık 720 bin iş̧̧inin bu haktan yararlanması öngörülmektedir. 
Kamuda kadroya alınacak işçilerin "Özel Sözleşmeli Personel” olarak istihdam edileceği öngörülmektedir. Özel sözleşmeli personel modeli, 657 sayılı Devlet Memurları Kanunu ve diğer kanunların sözleşmeli personel çalıştırılmasına dair hükümlerine tabi olmaksızın alt işveren işçilerinin atamalarının yapılabilmesi ve bunlar aracilığıyla yürütülen hizmetlerin aynı şekilde sürdürülmesi amacıyla oluşturulan yeni bir sözleşmeli personel çalıştırma modeli olarak ifade edilmiştir. Bu modelde, kişinin "Özel Sözleşmeli Personel” unvanlı pozisyona atanması, sosyal güvenlik yönünden 4/a’lı (SSK) olması ve memur sendikaları kapsamında toplu sözleşme hakkı bulunması öngörülmektedir.

Kamuda istihdam edilen alt işveren işçilerinin kadroya atanmasına yönelik çalışmalar devam etmektedir. Öngörülen özel sözleşmeli personel modeli, 657 sayılı Devlet Memurları Kanunu’nda yer alan memur, sözleşmeli personel, geçici personel ve işçi dışında yeni bir istihdam statüsüdür. Kamuda alt işveren bünyesinde çalışan ve çoğu zaman mağdur olan işçilerin kadroya alınarak "güvence"ye kavuşturulması çok önemli bir adımdır. Ancak, özel sözleşmeli personel gibi farklı ve nasıl şekilleneceği net belli olmayan bir statünün getirilmesi uygulamada yeni bir takım problemleri de birlikte getirecektir. Bu nedenle kamuda alt işveren bünyesinde çalışan işçilerin doğrudan "işçi" kadrosuna alınması daha sağlıklı çözüm yolu olacaktır.

\section{Sonuç}

İş Hukukunda asıl olan işverenin kendi işçisi ile mal veya hizmet üretmesidir. Ancak, çeşitli ekonomik ve teknolojik sebeplerden dolayı işverenler, bazen işin bir bölümünü başka bir işverenin işçileri vasıtasıyla yapmaktadırlar. Özellikle, teknolojik gelişmelerin ortaya çıkardığı yeni uzmanlık alanları, maddi imkânsızlıklar, kamudaki kadro kısıtlığı, amansız rekabet şartları gibi bir takım mali ve teknik sebeplerden dolayı işverenler, kendi istihdam ettikleri iş̧̧ilerle birlikte başka işverenin işçilerinin devreye girdiği alt işveren ilişkisi gibi düzenlemelere de yönelmektedirler. Alt işverenlik, işverene işyerindeki mal veya hizmet üretimini başka bir işverenin iş̧̧ileri vasıtasıyla gerçekleştirme imkânı sağlayan bir uygulamadır. Günümüzde yoğun bir uygulama alanı bulan alt işverenlik bir nevi "istihdam modeli" hüviyetine dönüşmüştür. Türkiye'de resmi kayıtlara göre yaklaşık 1,5 milyon alt işveren işçisi bulunmaktadır. Alt işveren işçilerinin ücret, kıdem tazminatı, yıllık izin gibi özlük haklarına yönelik sorunları bulunmaktadır. Son dönemde yapılan bazı yasal düzenlemelerle kamu kurum ve kuruluşlarda çalıştırılan alt işveren işçilerine yönelik ücret, kıdem tazminatı ve yıllık izin haklarına ilişkin bir takım iyileştirmeler yapılmıştır.

Alt işverenlik konusunda ana hatlarılya iki temel yaklaşımdan bahsedilebilir. Söz konusu yaklaşımlar alt işverenliğe bakışta, sorunu algılama biçiminde ve çözüm önerilerinde doğal olarak farklılık göstermektedirler. Birinci yaklaşıma göre alt işverenlik özellikle 1980’li yıllardan sonra ortaya çıkan ekonomik ve teknolojik değişmelerin ortaya çıardığı amansız küresel rekabet altında kalan işletmelerin varlıklarını sürdürebilmeleri için bir gerekliliktir ve İş Kanunun temel felsefesinde bulunan güvence-esneklik düzleminde piyasa şartları da dikkate alınarak alt işverenliğine ilişkin katı hükümler kaldırılmalı veya esnetilmelidir. İkinci 
yaklaşımda ise alt işverenlik ucuz ve sendikasız işgücü oluşturma gayesiyle oluşturulan ve çalışanların kazanımlarını ortadan kaldıran bir çalışma modeli olduğundan mevcut alt işverenlik uygulamasının İş Kanununun temel yaklaşımı olan iş̧̧inin korunması ilkesinden hareketle alt işverenlik uygulaması sonlandırılmalıdır. Ancak bir üçüncü yaklaşım olarak çalışanların haklarını garantiye alan teknolojinin ve işyeri ihtiyaçları doğrultusunda mevcut yapıdaki olumsuzlukları da ortadan kaldıran bir alt işverenlik mekanizması geliştirilmelidir.

Mevcut alt işverenlik uygulaması tarafları memnun etmemektedir. Yeterince esneklik getirmediğinden bahisle tenkit edilen alt işverenlik aynı zamanda örgütlenmeye engel olduğu ve hak kayıplarının yaşanmasına sebep olduğu gerekçeleriyle de eleştirilmektedir. Bu yüzden özellikle kamuda bir istihdam şekline dönen alt işverenlik uygulamasının acilen gözden geçirilmesi ve yaygın bir kamu çalıştırma modeli olmayacak şekilde yeniden düzenlenmesi gerekir.

Alt işverenliğe ilişkin yapılacak düzenlemenin, çalışanın korunması fikrini göz ardı etmeyen, özellikle, işyerlerinin sendikasızlaştırılmasına engel olmayacak bir mahiyette olması gerekir. Alt işverenliğin teknolojik veya işletme gerekliliği ile çalışanların sosyal haklarının korunması ilkelerinin birlikte değerlendirildiği bir sistem olarak oluşturulması gereklidir. Alt işverenliğin kötü niyetli ve istismara yol açan uygulamalarının önlenmesi için sosyal tarafların katılımı ile yeni mekanizmalar geliştirilmelidir.

Kamuda alt işverenlik, siyasi partilerin son dönem seçim beyannamelerinin önemli bir gündem maddesini oluşturmuş ve alt işveren çalışanlarına yönelik çeşitli çözüm önerileri getirilmiştir. 64. Hükümet tarafından (2016) kamu işyerlerindeki personel çalıştırılmasına dayalı hizmet alım işlerinde çalışan işçilerin kadroya alınması ve söz konusu işçilerin "Özel Sözleşmeli Personel" olarak istihdam edilmesi öngörülmüştür. Öngörülen özel sözleşmeli personel modeli, 657 sayılı Devlet Memurları Kanunu’nda yer alan memur, sözleşmeli personel, geçici personel ve işçi dışında yeni bir istihdam statüsüdür. Kamuda alt işveren bünyesinde çalışan ve çoğu zaman mağdur olan işçilerin kadroya alınarak "güvence"ye kavuşturulması çok önemli bir adımdır. Ancak, özel sözleşmeli personel gibi farklı ve nasıl şekilleneceği net belli olmayan bir statünün getirilmesi uygulamada yeni bir takım problemleri de birlikte getirecektir. Bu nedenle kamuda alt işveren bünyesinde çalışan işçilerin doğrudan "işçi" kadrosuna alınması daha sağlıklı çözüm yolu olacaktır. 


\section{Kaynakça}

Ak Parti, (2015), Huzur ve İstikrarla Türkiye’nin Yol Haritası, 1 Kasım 2015 Genel Seçimleri Seçim Beyannamesi, http://www.akparti.org.tr/upload/documents/1-kasim-2015-secim-beyannamesi. pdf (Son erişim:01.06.2016)

Ak Parti, (2016), Ekonomi İşleri Başkanlığı, Taşeron İşçisine Kadro Müjdesi, Ekonomi Bülteni Sayı:

2 Mart. http://www.kamupersoneli.net/images/upload/bro\%C5\%9F\%C3\%BCr.pdf (Son erişim:01.06.2016)

Akyiğit, E. (2015). “Kamuda Asıl İşin Bir Bölümü Alt işverene verilirken Muafiyet Var mıdır?” Çalışma ve Toplum Ekonomi ve Hukuk Dergisi, DİSK Birleşik Metal-İş Sendikası, 2015/2 http://www. calismatoplum.org/sayi45/akyigit.pdf (Son erişim:01.06.2016)

Aykaç, H. B. (2010). İş Hukukunda Alt İşveren, Ankara Üniversitesi, Sosyal Bilimler Enstitüsü Özel Hukuk (İş ve Sosyal Güvenlik Hukuku) Anabilim Dalı, Yayımlanmamış Doktora Tezi, Ankara.

Başbakanlık 64. Hükümet 2016 Yılı Eylem Planı (İcraatlar ve Reformlar) 10.12.2015, http://www.akparti. org.tr/upload/documents/64.hukumet-eylem-plani-kitap.pdf (Son erişim:01.06.2016)

Canpolat, T. (2010). “Türk Hukukunda Alt İşveren: Borçlar Hukuku Bakımından” Tebliğ, Kamu İşyerlerinde Alt İşveren Uygulamasının Doğurduğu Sorunlar ve Çözüm Arayışları Semineri/Çalıştayı, Kamu İşletmeleri İşverenleri Sendikası (KAMU-İŞ), 29 Nisan-02 Mayıs. Antalya, http://www.kamu-is. org.tr/pdf/altisverenkitap.pdf (Son erişim:01.06.2016)

Çelik, A. (2014). “Müjde Yok, İlelebet Taşeronluk Var!, 31 Mayıs 2014 https://azizcelik.org/2014/05/31/ mujde-yok-ilelebet-taseronluk-var/ (Son erişim:01.06.2016)

Çelik, N. (1994). İş Hukuku Dersleri, Yenilenmiş 12. Bası, Beta Basım Yayım Dağıtım A.Ş., İstanbul.

CHP, (2014) TBMM 5. Yasama Yılı, 24 Yasama Dönemi 656 Sıra Sayılı Türkiye Büyük Millet Meclisi Plan ve Bütçe Komisyonu 2015 Yılı Merkezi Yönetim Bütçe Kanunu Tasarısı Raporu 2015 Yılı Merkezi Yönetim Bütçe Kanunu Tasarısı (Rapor ve Metin) Cilt:1. 3 Aralık.

CHP, (2015), Önce İnsan, Önce Birlik, Önce Türkiye, 1 Kasım Seçim Bildirgesi, https://www.chp.org.tr/ Public/0/Folder//52608.pdf (Son erişim:01.06.2016)

ÇSGB, (2014) Faruk Çelik Çalışma ve Sosyal Güvenlik Bakanı, Mersin Milletvekili Ali Öz’ün 7/44973 Esas Numaralı Yazılı Soru Önergesine Dair Cevap, 22.10.2014, http://www2.tbmm.gov.tr/d24/7/744973sgc.pdf (Son erişim:01.06.2016)

ÇSGB, (2015) Faruk Çelik Çalışma ve Sosyal Güvenlik Bakanı, Malatya Milletvekili Veli Ağbaba’ya Ait (7/43275) Esas No’lu Soru Önergesine Cevap, 01.05.2015 http://www2.tbmm.gov.tr/d24/7/743275sgc.pdf (Son erişim:01.06.2016)

ÇSGB, "Alt İşverenlik Uygulaması, Yapısı Gereği Örgütlenmeyi ve Toplu İş Sözleşmesinden Yararlanmayı İmkânsızlaştırıyor" haberi, 01.11.2012, http://www.csgb.gov.tr/csgbPortal/csgb. portal?page $=$ haber\&id $=$ basin 491 (Son erişim:01.06.2015)

Demir, F. (2003). İş Güvencesi ve 4857 Sayılı İş Kanunun Başlıca Yenilikleri, Türkiye Haber İş Sendikası, İzmir, http://www.haberis.org.tr/uploads/files/kitaplar/yayin24.pdf (Son erişim:01.04.2016)

Demircioğlu, A. M., Tankut C. (2012), İş Hukuku (Bireysel İş Hukuku, Toplu İş Hukuku), Beta Basım Yayım Dağıtım A.Ş, 15.Baskı, İstanbul.

DPB, (Devlet Personel Başkanlığı) (2015), İstatistikler, 20.05.2015, http://www.dpb.gov.tr/F/Root/dosyalar/ istatistikler/kamu_per_istatistikleri/mayis2015/1_kamuPersonelistihdamRakamlar.pdf ～(Son erişim:01.06.2016)

Eryiğit, S. (2010). Kamu İşyerlerinde Alt İşveren Uygulamasının Doğurduğu Sorunlar ve Çözüm Arayışları Semineri/Çalıştayı Takdim Konuşması, Kamu İşletmeleri İşverenleri Sendikası KAMU-İŞ tarafından, 29 Nisan-02 Mayıs 2010 Antalya, http://www.kamu-is.org.tr/pdf/altisverenkitap.pdf 
(Son erişim:01.06.2016)

Görmüş, A. (2013). "Kamu Kurumlarında Hizmet Alımı Yoluyla İstihdam Edilenlerin Kıdem Tazminatı Sorunu”, Çalışma ve Toplum Ekonomi ve Hukuk Dergisi, DİSK Birleşik Metal-İş Sendikası, Sayı:3, http://calismatoplum.org/sayi38/gormus.pdf (Son erişim:01.06.2016)

Güzel, A. (2010). "Alt İşveren Uygulamasında Güvencesiz Bir Sisteme Doğru”, Çalışma ve Toplum Ekonomi ve Hukuk Dergisi, DİSK Birleşik Metal-İ̧s Sendikası, Sayı:4, http://calismatoplum.org/sayi27/ guzel.pdf (Son erişim:01.06.2016)

Güzel, A. (2004). “İş Yasasına Göre Alt İşveren Kavramı ve Asıl İşveren - Alt İşveren İlişskisinin Sınırları”, Çalışma ve Toplum Ekonomi ve Hukuk Dergisi, DİSK Birleşik Metal-İş Sendikası, Sayı:1, http:// www.calismatoplum.org/sayi1/makale2.pdf (Son erişim:01.06.2016)

HDP, (2015), Büyük İnsanlık, 2015 Seçim Bildirgesi http://www.hdp.org.tr/images/UserFiles/Documents/ Editor/HDP\%20Se\%C3\%A7im\%20Bildirgesi\%20Tam\%20Metin.pdf (Son erişim:01.06.2016)

Kalkınma Bakanlığı, (2014). İstihdam ve Çalışma Hayatı, Özel İhtisas Komisyonu Raporu, Ankara.

Koç, M. (2005). “İş Kanununda Alt İşveren Kavramı ve Unsurları”, Kazancı Hukuk, İşletme ve Maliye Bilimleri Hakemli Dergi, Sayı:6, Şubat. 87-98

Kurt, R. (2006). İş Hukuku Mevzuatında Usul ve Esaslar, İSMMMO. İstanbul

Memur Haber (14.05.2015), “Çalışma Bakanı’ndan Flaş Taşeron Açıklaması” Haberi. http://www. memurhaber.com/calisma-bakanindan-flas-taseron-aciklamasi-h49530.html

MHP (2015), Huzurlu ve Güvenli Gelecek, Ülkenin Geleceği, 1 Kasım 2015 Seçim Beyannamesi, https://www.mhp.org.tr/usr_img/mhpweb/1kasimsecimleri/taahhutler_1kasim2015.pdf （Son erişim:01.06.2016)

Milliyet Gazetesi, “1.36 Milyon Taşeron Çalışıyor.”26.11.2014, http://www.milliyet.com.tr/1-36-milyontaseron-calisiyor-gundem-1975085/ (Son erişim:01.06.2016)

Mollamahmutoğlu H. (2004), 4857 Sayılı Yeni İş Kanunu’nun Getirdiği Önemli Bazı Yenilikler Kamuİş İş Hukuku ve İktisat Dergisi, C:7, S: 4/2004, http://www.kamu-is.org.tr/pdf/741.pdf (Son erişim:01.06.2016)

Okcan, N., Onur B. (2010) "İşletmenin ve İşin Gereği Taşeronlaştırma”: Taşeron Cumhuriyetine Doğru..., Çalışma ve Toplum Ekonomi ve Hukuk Dergisi, DİSK Birleşik Metal-İş Sendikası, 2010/4, 68-73, http://calismatoplum.org/sayi27/okcan-bakir.pdf (Son erişim:01.06.2016)

Özdemir, G. Y. (2010), “Despotik Emek Rejimi Olarak Taşeron Çalışma”, Çalışma ve Toplum Ekonomi ve Hukuk Dergisi, DİSK Birleşik Metal-İş Sendikası, 2010/4, http://www.calismatoplum.org/sayi27/ ozdemir.pdf (Son erişim:01.06.2016)

Özveri, M. (2008), “İş Hukukunun Altının Oyulması”, Tes-İş Dergisi, Mayıs. http://www.muratozveri. net/?p=188 (Son erişim:01.06.2016)

SGK, (2015), Aylık Sigortalı İstatistikleri (Aralık 2014), 01.09.2015, http://www.sgk.gov.tr

Soyer, P. (2013), “4857 Sayılı İş Kanunu’nun 10. Yllında Asıl İşveren-Alt İşveren İlişkisi ile İlgili Genel Bir Değerlendirme”, Türkiye İşveren Sendikaları Konfederasyonu, 10. Yılında İş Kanunu Semineri, 15 Kasim 2013, İstanbul.

Süzek, S. (2009), İş Hukuku (Genel Esaslar-Bireysel İş Hukuku), Beta Basım Yayım Dağıtım A.Ş, .5.Baskı, İstanbul.

Şafak, C. (2004). “4857 Sayılı İş Kanunu Çerçevesinde Taşeron (Alt İşveren) Meselesi”, TBB Dergisi, Sayı:51, http://tbbdergisi.barobirlik.org.tr/m2004-51-5 (Son erişim:01.06.2016)

Şahlanan, F. (2014). “Kamu İşyerlerinde Alt İşveren Uygulamasının Doğurduğu Sorunlar ve Çözüm Arayışları”, İstanbul Üniversitesi Hukuk Fakültesi Mecmuası, C.LXXII, S:2, http://www.journals. istanbul.edu.tr/iuhfm/article/viewFile/5000035127/5000034288 (Son erişim:01.06.2016)

Şakar, M. (2010). “Ölçüsüz Taşeronlaşmaya Karşı Önlemlerde Geri Adım: İş Sağlı̆̆1 ve Güvenliği Kanun 
Tasarısı Taslağına Sıkıştırılan Değişikliğin Değerlendirilmesi", Çalışma ve Toplum Ekonomi ve Hukuk Dergisi, DİSK Birleşik Metal-İş Sendikası, Sayı:/4, http://calismatoplum.org/sayi27/sakar. pdf (Son erişim:01.06.2016)

Şen, S. (2003). "Yeni İş Yasasında Alt İşverenlik", Sendikal Notlar Dergisi, Ağustos (www.isyeri.tk, Son Erişim: 01.07.2004)

Şen, S. (2006). "Alt İşverenlik ve Asıl İşin Bir Bölümünün Alt İşverene Verilmesi”, Çalışma ve Toplum Ekonomi ve Hukuk Dergisi, DİSK Birleşik Metal-İş Sendikası, Sayı:3, http://www.calismatoplum. org/sayi10/S_sen.pdf (Son erişim:01.06.2016)

TDK, Türk Dil Kurumu, Güncel Türkçe Sözlük, www.tdk.gov.tr

TİSK, (2012) Türkiye İşveren Sendikaları Konfederasyonu, Soru, Cevap ve Sorunlarıyla İş Hukukunda Alt İşveren, 15 Şubat 2012 Yayın No: 318.http://tisk.org.tr/tr/e-yayinlar/soru_cevap_ve_sorunlariyla_ is_hukukunda_alt_isveren/pdf_soru_cevap_ve_sorunlariyla_is_hukukunda_alt_isveren.pdf (Son erișim:01.06.2016)

Turan, K. (1990), İş Hukukunun Genel Esaslar, Kamu-İş (Kamu İşletmeleri İşverenleri Sendikası), Ankara.

Yazıcı, E. (2014), Taşeron İşçisi Gerçeği Araştırması, Kimlik, Tutum, Beklenti Raporu, Hak İşçi Sendikaları Konfederasyonu, Ankara.

Yenisey, K. D. (2009), “Asıl İşveren-Alt İşveren İlişkisi ve Bu İlişkiden Kaynaklanan Hukuki Sorunlar”, Asıl İşveren-Alt İşveren İlişkisi ve Uygulamadaki Sorunlar Paneli, 21 Şubat 2009 Antalya, İş Müfettişleri Derneği Yayınları, 2010, Ankara.

Yüce, E. (2010). Kamu İşyerlerinde Alt İşveren Uygulamasının Doğurduğu Sorunlar ve Çözüm Arayışları Semineri/Çalıştayı, Açılış Konuşması, Kamu İşletmeleri İşverenleri Sendikası KAMU-İŞ. 29 Nisan-02 Mayıs 2010 Antalya, http://www.kamu-is.org.tr/pdf/altisverenkitap.pdf (Son erişim:01.06.2016) 